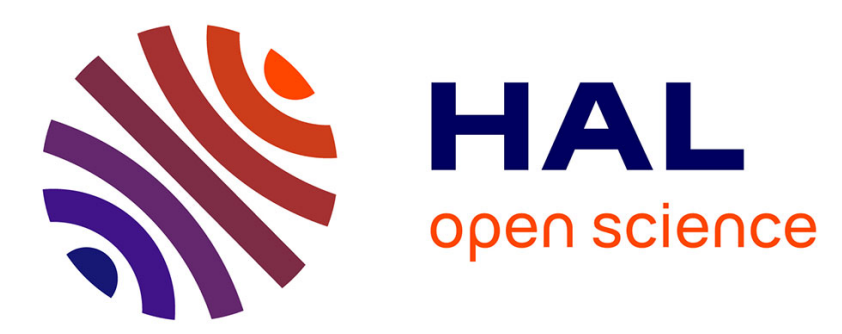

\title{
The Transformations of the Justice and Development Party in Morocco in the Face of Urban Governance Myriam Catusse, Lamia Zaki
}

\section{To cite this version:}

Myriam Catusse, Lamia Zaki. The Transformations of the Justice and Development Party in Morocco in the Face of Urban Governance. Myriam Catusse, Karam Karam. Returning to Political Parties? Political Party Development in the Arab Word, Presses de l'IFPO / Lebanese Center for Policy Studies, pp.18, 2010, Etudes contemporaines. halshs-00554017

\section{HAL Id: halshs-00554017 https://shs.hal.science/halshs-00554017}

Submitted on 10 Jan 2011

HAL is a multi-disciplinary open access archive for the deposit and dissemination of scientific research documents, whether they are published or not. The documents may come from teaching and research institutions in France or abroad, or from public or private research centers.
L'archive ouverte pluridisciplinaire HAL, est destinée au dépôt et à la diffusion de documents scientifiques de niveau recherche, publiés ou non, émanant des établissements d'enseignement et de recherche français ou étrangers, des laboratoires publics ou privés. 


\title{
Chapter 6
}

\section{The Transformations of THE Justice and DeVelopment Party IN MOROCCO IN THE FACE OF URBAN GOVERNMENT}

\author{
Myriam CATUSSE and Lamia ZAKI*
}

This chapter tackles the transformations that affect the elected local representatives of the Justice and Development Party (PJD - bið̌b al-'adâla wa al-tanmiya) in Morocco, based on their term in office. Examining the profile and activities of the representatives of this new party on the political scene, it questions the transformations of its ideology, the political innovations that it brings about and finally, the internal and external constraints that weigh upon partisan life in Morocco.

In June 2009, the City Council elections in Morocco have been held. The mandate that ended was singular on several accounts. In the first place, it inaugurated the institutional mechanisms of the new Communal Charter adopted in 2002, which re-divided the administrative map (districts) of the country upon a royal command for decentralization. Each of the big agglomerations that counted more than 500000 inhabitants in the 1994 census (Rabat, Sale, Casablanca, Fes, Marrakech, and Tangier), and that were until then divided into several urban communities, were "unified" into only one commune headed by a councilor. As a result the 27 communes of Casablanca were united into only one municipality that henceforth integrates 131 city councilors (they numbered 1147 before the Chart). The president of the city council acquired more prerogatives and commentators begin to call him "mayor" although the term does not figure in the text of the Charter.

The 2003 local elections were also marked by the entry of the PJD, that ran for the first time in local elections. This political group was born at the end of the 1990s of a rapprochement between a party without a base, the Constitutional and Democratic Popular Movement (MPDC - al-haraka al-chabiyya al-dimuqrâtiyya wa al-dustûriyya) established in 1967 by an old statesman, minister and speaker of parliament, Abdelkrim al-Khatib, and the Movement of Unity and Reform (MUR - al-islâh wa al-tawhîd). The latter itself is the heir of the Islamic Brotherhood (al-jamâ'a al-islamiyya) and the Islamic Youth (al-chabîba al-islâmiyya), two dissident movements that were undergoing a process of legalization during the 1990s (Tozy, 1999). On the Moroccan political scene of the 2000's the PJD represents the principal legal party formation that proclaims an "Islamic" frame of reference. In contrast with the Justice and Charity association (al-'adl wa al-ihsân), led by the charismatic opposition figure Cheikh Yassine, the PJD entered the formal political field since its formation and engaged in the electoral process by participating in the 2002 legislative elections.

Comforted by the results it achieved in the parliament that year (the party came in third position with 42 seats out of 321) and following the Turkish AKP, the leaders and

\footnotetext{
* Dr. Myriam Catusse is CNRS researcher at the Institut Français du Proche Orient (Beirut). Dr. Lamia Zaki is a researcher at the Institut de recherche sur le Maghreb Contemporain (Tunis). This chapter is a revised and translated version of M. Catusse and L. Zaki, « Gestion communale et clientélisme moral au Maroc: les politiques du Parti de la justice et du développement », Critique internationale, n 42 , janv. / mars 2009.
} 
militants of the party declared clearly their intentions to "take over the cities" in the 2003 local elections. However, the Casablanca attacks on May 16, 2003 put a brake on the party's zeal, as it was accused by its rivals of being "morally responsible" for the political violence through the diffusion of a radical ideology among unprivileged sections of society. Some key figures went so far as to call for a ban on the party. Party officials therefore decided, without disappointing their party base, to limit candidatures to $18 \%$ of electoral districts and to only half of the arrondissements in cities with more than 500,000 inhabitants. None of the main party officials ran for elections, and very few PJD parliamentarians headed the electoral lists. Ultimately, the political party only supported $3.48 \%$ of the candidates.

Despite this limited participation, the PJD achieved a remarkable victory in the local elections, mainly by targeting the choice of candidatures. Arriving in 11th place in terms of elected representatives on the national level, the party is henceforth the second power of the kingdom on the scale of medium-sized cities (the party is effectively absent from rural districts). It won the presidency of 17 municipalities, among which some like Meknes and Temara were promoted to the frontline of the party's politics. In the large urban areas endowed with a city council, the PJD is largely represented but does not hold the presidency. Loyal to its strategy of auto-limitation (largely imposed by the central power), the party did not run for elections in Tangier or in Agadir, where results of the 2002 legislative elections suggested that it could have realized good scores. In Casablanca, where the party ran for elections, it came first in seven arrondissements out of eight (the city counts 16).

The 2003-2009 municipal mandate thus constituted a phase of political apprenticeship for the elected representatives of the PJD. In addition to the fact that it was often a first experience for them, they faced as the other elected representatives "teething troubles" in the application of the new Charter. They were equally forced to adjust to the constraints of an ambiguous decentralization: the central power effectively strengthened the local authorities while in parallel providing the devolved administration (autorités déconcentrée) wali (regional prefect) and governors (prefects) - with the essential resources and prerogatives for urban action (De Miras, 2005). In this context, those who previously pretended to attack the cities today present themselves as pragmatic managers of the local in line with calls for good neoliberal governance. The religious reference becomes less marked or, more specifically, declines and readjusts to the local level, contingent upon the public and centered around some consensual watchwords (proximity, integrity, morality) (Smaoui, 2009). In fact, the PJD elected representatives tend to promote a "politics of doing", in a context of competitive clientelism and within the institutional and political limits of Moroccan decentralization. In sum, these new city managers present the characteristics of the good man, indeed those of a notable; however, they are also the apparatchiks, the real kingpins of the party on the local scale.

\section{A Management Discourse}

\footnotetext{
${ }^{1}$ We refer notably to the works of C. Goirand (2000) who shows that in Brazil, in the context of political liberalization, local notables engage themselves in "politics of doing," attempting to win voters by doing more, better and differently than their rivals. See also L. Zaki (2005, chap. 7).
} 
In a December 2005 issue, Le Journal Hebdomadaire published a feature dedicated to the "pragmatism of the PJD mayors." " The "realism of local politics" and the "efficiency of community management" of the newly elected representatives were presented as the "keys for success" of the party. After pronouncing the party responsible for the May 2003 attacks, the national media - in addition to the international one ${ }^{3}$ - portrayed the elected representatives as sensible managers: the journalists who so dreaded a "shift to the Algerian experience" finally announced a more "Turkish transition ."

According to them, the virtues of what PJD elected representatives perceive as Islamist political work relies less on know-how than on the will to do good and less on practical experience than on authenticity of commitment. For its part, the PJD holds a noticeably different viewpoint. The discourse of its representatives about the city draws on tested repertoires of urban management, and pragmatism takes first place in the decisionmaking process on the ground". This managerial "label" is at the heart of the legitimization strategies of the elected PJD representatives. ${ }^{5}$ When asked about their municipal track record, they highlight above all the good management of the budget: "We don't have distinctiveness in terms of themes or programs compared with others. Our distinctiveness is perhaps more the management." (W., PJD elected representative of Casablanca, vice-president in charge of urbanism in the City Council, July 2008)

It should be noted that the question of the political economy of the cities has figured on top of the public agenda since the mid-1990s. The new Charter transformed the rules of the game and the scale of redistribution of resources. The arrondissements that replaced the municipalities in the big cities have neither a legal personality nor a proper budget (their restricted funds are allocated by the City Council). They became limited to only three illdefined prerogatives: the so-called politics of proximity, the registry office and the issuing of construction permits for individual housing. As for the elected local representatives, they are generally accused of mismanaging public accounts (due to incompetence or corruption) and are often the object of financial audits (Catusse, 2001). In all cases, the economic dependency of the local representatives on the central authorities, the ultimate instance with power to authorize expenditure, remains decisive and only leaves a small margin for maneuvering.

In reaction, the PJD representatives in the municipalities seek to prioritize their management responsibility, their capacity not only to keep accounts, but also to be accountable: "If there is an added value to the PJD, it is above all this enthusiasm and the will to have a healthy local management... without needing to disburse something to someone or to the party. Through transparency and for the good of the citizens. Not for personal interests or business issues. Trying to curb expenditures to the maximum, avoiding the squandering of public money and increasing the returns to the municipality.” (R. President of the Temara municipality, PJD, July 2008)

Putting this management ethic into practice was often learned on the job and several elected representatives confess that they discovered the accounting rules at the beginning of their mandate. Moreover, they use the metaphor of the enterprise to describe the way their municipality functions. In the case of Temara, the PJD mayor underlines not only the "capacity for synergy" of the party with other majority groups of the city council, but

\footnotetext{
${ }^{2}$ Le Journal hebdomadaire, 234, du 10 au 16 décembre 2005.

3 Jacques Bertoin, «Islam, business et vidéo », Jeune Afrique, 11 avril 2004.

${ }^{4}$. For a comparative approach, see M. Leclerc-Olive (2005) and on Morocco Catusse (forthcoming)

5. Politix, 20 (79), 2007, dossier « Management».
} 
also the favorable collaboration of the municipality with public authorities, and in particular, with the prefecture. This "very participatory and consultative" approach allows him to develop a "strategy of planning" over ten years, thanks to recourse to a private chartered accountancy firm that drafted the action plan. The mayor recalls the restructuring efforts of the municipal administration that he launched in order to improve the functioning of what he calls his "municipality-enterprise." The economic reason takes precedence over the social one in order to justify the need to decrease staff, but equally to outsource certain functions in order to respond more effectively to the increasing needs of the city. The loan received by the City Council from the local equipment funds contributed to the high growth of the municipality's budget (that was doubled in five years). Indeed, the recourse to credit could "provoke reactions among people [in the PJD] that were not working in the municipalities", but the mayor recalls that "there should be a certain flexibility in the values [of the party] in order to adapt to realities."

For him, it is this "spirit of entrepreneurship in the management of the city" that explains how Temara is the first municipality where a semi public company (SEM), specialized in the construction of social housing and urban infrastructure, was established with the Funds of Taxes and Management ${ }^{7}$. The municipality is the main shareholder, along with private or semi-public partners: "Different projects should be carried out without worrying too much about the social. For this reason the SEM is a good idea. (...) the staff of the municipality is not trained for this. The SEM was created for operational projects. And sometimes the municipality can also delegate mandated projects for the construction of markets [souks, covered or open], etc. The people of the municipality take care of the rest: the registry office..." (R.)

Even though the initiative for technical projects or for the rationalization of public action, often relatively consensual, does not necessarily concern them, party officials do not hesitate to take on the implementation themselves: "the idea of one counter only (for the urbanism files), it was not us, but it was us who did it... we installed electronic tickets that indicate the date on which the commission will meet. The procedures now take fifteen days instead of six to seven months previously." (W. PJD elected representative, Casablanca, July 2008)

The economic argument therefore is omnipresent in the approach of the PJD representatives. In Casablanca, they are indignant that the law on competitiveness was flouted in an invitation for bids to set up a supermarket. In Fez and Rabat, where they are in the opposition, they request (with success) the intervention of the Audit Court in order to sanction bad management, including the embezzlement by two mayors. In their own municipalities, they work hard to attract investments while taking advantage of real estate: "Two big supermarkets were opened in the space of three months. Industries and services were set up. Temara is now the place where the square meter is the most expensive... (...) Sustainable sources of revenue for the city should be created.” (R.)

Finally, particularly in Casablanca where the party is in the majority, it is opposed to the terms and conditions of renegotiation of the management contract for the city's water and electricity networks awarded since 1996 to Lydec (Lyonnaise des Eaux de Casablanca), subsidiary of Suez Environnement. An elected PJD representative

\footnotetext{
${ }^{6}$. The practice of usury, al-ribâ, is prohibited by Islam. This allowed the development, namely since the 1990s, of a system of «Islamic finance » (Rousillon, 1989).

${ }^{7}$ A law is currently under preparation to organize the regulation of this kind of contract.
} 
specialized in this field for the sake of optimizing the management of public services. The review of the contract, signed in November 2008, was in this way partially controlled by the municipality thanks to the joint action of the PJD and the opposition, notably of the Socialist Union of Popular Forces (USFP), the main national and local rival of the PJD.

The party officials seem to equally subscribe to the connection between public management and private management, a recurrent connection in Morocco during the years of liberalization (Catusse, 2008). So they praise the managerial qualities of the mayor of Casablanca. A manufacturer, an ex-president of the Chamber of Commerce, Industry and Services of Casablanca and an elected representative of the Constitutional Union, he developed his professional activities in Taroudant in the south of the country: "It is the first time in history that Casablanca has a president with a graduate background, an HEC graduate of Paris in 1974, who has been around. He was in business for twenty years as a big developer. It is those who have an adequate training, a great experience in career, in business, who can succeed. I don't understand how a president of an enterprise who went bankrupt can do politics. Because if he did not succeed in his private life, I do not see how he can succeed in his life in the community". (O. PJD elected representative, Casablanca, July 2008)

This management profile, however, can appear paradoxical on the part of a party that, as we will see, mobilizes very little in the world of business. Figureheads compensate this deficit, notably in Meknes, the biggest city in the kingdom governed by the PJD. In this city presented as a showcase for the party after the victory it realized in 2003 , the new elected mayor is a rich property owner dubbed so by the party on the eve of the elections. His profile as a notable constituted at the time of the election a source of legitimacy for the PJD. But his management style of urban policy demonstrates his limits and his state of grace is wearing off today. His attitude in the City Council is questioned. In order to pocket the profits of the state-owned and autonomous urban transport that he hopes to privatize, he did not hesitate to bloc the circulation of state buses during almost two years, provoking local protest and royal intervention in 2005 in order to reactivate public transport. Defeated in his council, he is henceforth hardly supported by his party, which no longer presents the city as a PJD management laboratory, but controls with care the declarations of mayor of the city. Perhaps the attitude of the latter, insufficiently concerned with the social needs of his citizens, appeared too costly for party officials?

\section{THE EUPHEMIZATION OF THE RELATIONSHIP WITH ISLAM}

The municipal practice of the PJD is equally marked by an euphemization of the relationship with religion. The political group moreover rarely makes reference to Arab Islamist parties overly associated with the Muslim Brothers (Zeghal, 2005) : it seems that a division of labor has been organized between the MUR and the PJD - the former taking charge of religious mobilization, the latter of political mobilization. If the religious reference is still present, other themes shape the rhetoric of the PJD, namely in terms of local governance (the "local questions" al-umûr al-maballiyya - to recapture the words of its leaders). 
In the beginning of the millennium, the party opposed a parliament vote on a law regulating microcredit, which was and still is a booming sector. PJD leaders denounced the practice of usury as contrary to Shariaa law. In light of the municipal experience, however, the PJD councilors readjusted their position: "We are not against interest rates. To whom belongs the capitalist economy? To the Christians? To the private sector? We are against these ideas. They are outdated. All that is good for humanity is good for us." (K., PJD elected parliamentarian, Mohammedia, July 2008)

In 2003, certain party candidates considered establishing a public transportation system, separating men and women: "As in Tehran, this would allow everyone to sit." (K., PJD elected representative, Moulay Yacoub, Rabat, February 2003) Today, the project seems barely feasible: "Society is not ready. We are not alone... We are working gradually. Maybe in the future?" (A., PJD elected representative, Sidi Bernoussi, Casablanca, July 2008) "It is not in Islam. These are customs. Islamic thought has to be reformed. We have windows [of interpretation] to create in Islam." (K., PJD elected parliamentarian, Mohammedia, July 2008) ${ }^{8}$

As for the discourse on social justice, still present, it addresses first and foremost the way of condemning thieves and the corrupt who become rich at the expense of citizens. In fact, the public rhetoric of the local leaders of the PJD is deliberately flexible with relation to the Islamic frame of reference: "We are a party of religious identity, but our religious side is not required to emerge clearly in local management." (A.)

This relative distancing does not exhaust the complex connections that the party maintains with organizations like MUR that explicitly proclaims an Islamic mission. On the ground, buildings of the party host courses in Qur'anic teaching, local associations close to the party organize scout activities for children (Smaoui, 2009) etc. Meanwhile, the concrete practice of municipal power leads the PJD to position itself in the Islamism arena by presenting itself as an antidote to forms of populism or radicalism using religious language. The party thus sets itself up as the defense against dangers presented as more serious than its own accession to power, not only for the secular camp but also more generally for the country. The political experience leads mainly to the implementation of pragmatic decisions. The PJD interviewees often evoked the Algerian scenario as a counter example. They stress that the PJD protects Morocco from terrorism, but also to suggest that if the Islamic Salvation Front (FSI) had been in power, "good sense" would have "naturally" pushed it towards normalized political strategies.

In fact, the favorite themes of the elected PJD representatives remain more moral and negotiable than strictly religious. Several local episodes illustrate the absence of a clear party line on the question of morals. They reveal more the positions taken by individuals and sometimes those taken by elected representatives than they are a product of national campaigns launched in defense of intangible principles. In Khenifra in 2005, a declaration by the PJD mayor of the city on the subject of its reputation as a "historical place of prostitution" provoked public controversy: one thousand people descended on the street at the call of leftist movements to express their indignation. The debate, however, revolves less around the place of religion in the city than around the social and moral disturbance that prostitution could bring about. As for the protests, they are less about the use of morals in politics (save for the Moroccan Human Rights Association) than the stigma that such declarations could bring to the citizens of the city. In Ksar el ${ }^{8}$. The interviewee refers to the religious principal of ijtibâd, an effort of reflection and interpretation of
holy texts. 
Kebir in 2007, another PJD municipality, the county court condemned six men for homosexuality. "Public manifestations of depravity must not take place in the state of the commander of the faithful," affirmed the leader of the PJD group at the Assembly of Representatives. But it was in a PJD town hall in Meknes that a wine party was organized in 2007. The mayor of this city is also a jury member of a beauty contest. There is no agreement on the question of bars within the party anyway. In 2003, the PJD president of a municipality in Rabat affirmed: "I will not sign a document on the planning of the corniche if hotels and bars will be found there. Even if Auchan settles there and sells alcohol. Do not insist on this." (K., Moulay Yacoub, Rabat) Today, the position of the party is clearly less uncompromising. In Meknes and Temara, the new PJD mayors boast about setting up hypermarkets in their municipalities, even if these markets sell alcohol. And while the PJD is opposed to the construction of a supermarket in a poor neighborhood of Casablanca, its representatives emphasize less the Muslim principle of prohibiting alcohol than the supermarket's incompatibility with consumers from working-class neighborhoods or slums. This condescending argument with regard to these populations demonstrates that the party does not necessarily make itself the porteparole of marginalized neighborhoods in the city as is claimed (Zaki, 2005): "The question of wine was secondary. There are groceries there, shopkeepers that will be ruined by a supermarket, and then there are minors in Lahraouiyine, streets where even a police van cannot cross, it would be a catastrophe to bring wine to these people." (L., PJD elected representative, Casablanca, July 2008)

\section{Managing Daily Problems: The Display of Moral Clientelism}

The third side of the PJD local policy is the effort that its representatives expend towards citizens and their social needs. Access to the municipal council serves less to implement ambitious programs than to put in place forms of personalized "social and institutional mediation" "with voters. In the end, the local elected representatives of the party develop an ideology of local public action not much different, at least in this respect, to that of the more traditional notables. They seem to have authority only to manage daily problems on the ground: "Day after day, I realized that the real place of the PJD was in the municipality. It is there where the citizen is, there that things have to be settled. The parliament flies above like an airplane, but the real problems are on the ground: everything that is local, is the ground." (L.)

The PJD councilors insist on the ethical dimension of this "mediation" carried out in the interest of the citizens and not motivated by personal interest: in order to economize the subsidy allocated to his district, a president of an arrondissement refused to change the furniture of his office when he installed himself in the new administrative centre whose construction he succeeded in finalizing. They highlight notably their availability, a quality that is at the heart of solving the daily problems of voters. "What concerns me the most is that citizens know that $\mathrm{A}$. is here from 11 to 1:00 pm." (A. PJD vice-president of the arrondissement, elected to the City council of Casablanca, July 2008)

\footnotetext{
9 Through analogy with the concept of "personalized political mediation" used by Javier Auyero (2001) to underline the importance of emotion and ties within a clientelist relationship, which is not limited to the distribution of goods and/or services in exchange for votes.
} 
They enter thus into competition with elected representatives of other parties in order to win the demands and grievances of the citizens. The vice-president of the arrondissement mentioned above (A.) evokes with pride the tensions that characterized his relationship with the president of the arrondissement during many months after the 2003 elections: "There was a line in front of my office, many people came to see me. On the other hand, on the floor [in front of the president's office] it was empty, there was no one. My relationship with the president was difficult, he did not accept that."

The PJD councilors' "politics of doing" is articulated principally at the local level around two types of intermediaries: an institutional one, where the elected representatives play the role of translators of the administrative demands of voters, and a more political and social one, through which the elected representatives use the (scarce) local and political party resources which they have in order to reinforce the link with voters. Part of their work is similar to the "administrative support" that consists of collecting requests of citizens in order to orient and to facilitate their demands (to get the doctor to provide a death certificate, to obtain administrative documents, etc.) It consists of explaining and accelerating procedures, no matter their nature, by approaching the manager of the ceremony hall of the arrondissement, for instance, in order to reserve the hall and to ensure that the reservation is validated by the signature of the president or the vice-president, or by obtaining the authorization of the president for an association to meet in the cultural center of the arrondissement. The elected representatives of the PJD try equally, notably by personalizing their ties with the technical services of the City Council, to obtain services for their citizens. This is more or less easy according to whether the party is in the majority or in the opposition of the City Council: "I learned that things are not given [in the City Council], they are caught, they are taken" (A.)

Negotiation is equally applied towards private enterprises in charge of the organization of public services (water, electricity, garbage collection). Elected PJD representatives emphasize the need to forge special ties with the representatives of these enterprises in order to obtain better results. Finally, personalized administrative mediation goes beyond the framework of decentralized administration to be deployed in the field of devolved administration (interventions addressed to the governor in order to accelerate certain steps namely for passports).

Even if they use their status and their networks in all these cases, the elected PJD representatives insist on the fact that the services provided are not subject to favoritism but that they are "normal" services that citizens have the right to claim legitimately. Their action aims at optimizing public services provided within the bounds of the law, contrary to other local political patrons who sometimes circumvent the law to satisfy their voters (Zaki, 2008). However, these methods are contested: opponents of the party perceive them as the manifestation of electoral clientelism ${ }^{10}$. The government for its part reproaches the PJD parliamentarians for making too many written questions in parliament on "local issues", and by doing so, for hindering the good functioning of institutions.

In parallel to this administrative support of citizens, who witness the gradual integration of the party in normalized and regular local action networks, the municipal PJD councilors deploy social activities often in accordance with the dense associational fabric gravitating around the MUR. Most of those we have met preside over one or several associations, and equally work in a more informal way in order to "to provide service to

${ }^{10}$ Mohamed Saâd Alami, “Le PJD est un parti clientéliste," Aujourd'bui le Maroc, June 52006. 
the citizen." In the Mohammedia district, they often attend the weekly duty of the PJD parliamentarian. The former equally calls on militants or volunteer "sympathizers," namely doctors and lawyers, who put their expertise to the service of voters. Networking is even more efficient since it relies on political party discipline presented as the "seal" of the party (words of the PJD mayor of Temara).

Meanwhile, this investment in the localized political mediation is not sufficient for compensating the reduction in institutional resources of the municipalities, notably on the scale of districts-turned-arrondissements. The new constraints that the government of the cities has to face are all the more politically costly since they are ill-digested by the voters. The PJD president of the arrondissement of Yaacoub el Mansour in Rabat has thus edited a manual recapitulating the prerogatives of the arrondissement and those relevant to the city, partly in order to clear his name vis-à-vis citizens who expected services of him that he is not able (or no longer able) to provide. The elected PJD representatives willingly highlight the difficulties that they have in assuming in their principal mission of community work and "local community-based services" ("proximite") Not only is it badlydefined, it would hardly make sense due to the low amount of subsidy allocated annually to the arrondissements by the City Council: "the elected representatives of the arrondissement have lost hope, they do not dare to say that they are elected. (...) we do not do local community-based services ourselves, we manage small problems.” (A.)

If the PJD in 2003 spoke in favor of unifying the municipalities, in virtue of the new Charter, a number of its elected representatives had to revise their position in light of facts. In their discourse, they set themselves up against "old elected representatives", whom they accuse of wanting to regain de facto the tasks that were taken away from the arrondissements, thus serving to feed the vagueness of the Communal Charter.

\section{Between Dissidence and Loyalty: Adapting to the Rules of the Local PARTY GAME}

By presenting candidates only in a limited number of arrondissements in the big cities even if they have been well elected - the PJD does not hold a sufficient majority to weigh in on local political decisions and even less so to redistribute resources of the territorial authorities. Since 2003, the president of the City Council of Casablanca monopolizes decision-making to the point of being considered the only master on board: he makes decisions with technical consultants (non-elected), he designates limited signatory authority by sector to members of the party and sets the order of the day on the agenda.

Moreover, it is the wali and the governors who decide in the final instance. The strategy of political normalization engaged by the PJD explains without a doubt the ambivalence of the elected representatives' discourse regarding relations with the devolved administration. On the one hand, they pledge allegiance to the power of tutelage, notably on the question of budget approval, demanding the replacement of a priori control by an ex post control rendering them accountable. On the other hand, they reclaim the arbitration of the central authorities "It is not possible to manage a city like Casa without the intervention of concerned ministries in Rabat. Casa should not be left to deal with its own problems. It is a big city but its resources do not suffice for real development, the 
problem is that the ministers and the public funds do not intervene except in rural Morocco.” (L., PJD elected representative, Casablanca, July 2008).

It follows that the PJD councilors seem sometimes tricked by the discrepancy between the symbolic effect that the 2003 elections represented and their limited capacity for holistic action. Their subscription to the rules of the local game saps in part their image as the porte-parole of protest. In Casablanca, for example, where it is the "spine" of the City Council (A., PJD elected representative, Sidi Bernoussi, Casablanca), the PJD has to compromise in order to prove its capacity to work in a team, far from the concept of "constructive criticism" adopted vis-à-vis the government from 1997 to 2002 (Zeghal, 2005). Thus, it counts only one elected representative in the board of the council, holding the same title as more weakly represented parties, whereas other parties have two elected representatives. Indeed, it is the only party to preside over three commissions in the City Council and to have obtained five vice-presidencies of commissions, while these latter hold hardly any power. The party, however, has accepted to preside over an incompetent budget commission on the question of financial resources, which relieves it of its tasks in another commission. In Casablanca, where it has won in seven arrondissements, the party has obtained finally only the presidency of Sidi Bernoussi. According to several of the councilors interviewed, it would have thus ceded to the pressure of power.

Nevertheless, the PJD elected representatives that we met display a strong loyalty towards their coalition in the city council. The oppositional stance is in fact associated with a certain political death at the local level: "In Morocco, in the municipality, no one chooses to be in the opposition. In the opposition, everything is blocked, we cannot do anything." (L., PJD elected representative, Casablanca)

The loyalty of the PJD councilors to the majority of the City Council enabled particularly the arrondissement of Sidi Bernoussi to obtain important financing from the City Council, upon which it now relies. The arrondissement would undoubtedly not have won this financing without the political concessions ceded by the party within the City Council. This financial manna permitted the completion of a cultural center and an administrative center work on which was started by the old municipal team more than ten years ago. And yet, the transfer of essential resources of the former municipalities-turnedarrondissements to the City Council (that reduced the budget of 13 million dirhams of the district of Sidi Bernoussi before the reform to 500,000 dirhams after 2003) largely limits the capacity for action of the elected representatives of the arrondissement.

These integration strategies of the majority of the City Council moreover can turn out to be politically costly for the party and lead to the disappointment, or even disaffection, of supporters. This was the case in the district of Casablanca-Anfa, where the majority of PJD militants campaigned for Abdelbari Zemzemi during the 2007 legislative elections. This former preacher ran under the colors of the Party of Renaissance and Virtue (PRV bizb al-nabda wa al-fadilla), while he had contributed largely to the establishment of the PJD in Anfa during the 2002 legislative elections. His candidature aimed in particular to oppose the common list presented by the PJD and the Party of Citizens' Forces (PCF biø̧b al-quwwat al-muwatana) - an alliance that formed part of the PJD's policy of normalization implemented by its management. While Zemzemi arrived in second, the candidate of the PCF was not elected: his defeat constituted an important setback for the PJD in a district where it obtained two elected representatives in 2002 (Wasif, 2009).

Entry into the city councils, however, did not totally blunt the capacity of the PJD to mobilize its supporters. During the last legislative elections of 2007, the party won in 
Casablanca with high results in six of the eight districts in which it ran. ${ }^{11}$ In Rabat, it also won to the detriment of the USFP, another opposition party in the City Council (Bennani Chraibi, 2008; Salgon, 2008).

\section{Professionals of Urban Government?}

While the 2003 Communal Charter requires candidates to prove a minimum level of education, equivalent to that of primary education (article 28), the PJD prides itself in an elitist ethic of political action. If party devotion lies at the source of accreditation of the party, the choice of candidates is also a function of other criteria guaranteeing the "competence" (kafâ'a) of elected PJD representatives, and essentially focusing on the professional and sociological profile of individuals: "We have managers, doctors, people who know how to talk...not illiterate people. We have graduates and well-known people, in order to represent the party well. We have to be representative of the party. We cannot choose just anybody to represent the PJD.” (A.)

Several political science studies point to an "entrepreneurisation" of political representation. Despite the rise to power of businessmen and local notables on the electoral stage, notably to the detriment of representatives from the educational sphere ${ }^{12}$, the PJD recruits more from the civil service than from private domain. Teachers represent a quarter of the PJD elected representatives in the City Council, while they represent 10,28\% of all parties on average (Elyagoubi, 2005) : time management is easier in the civil service, while private enterprises, whose logic is incompatible with the availability required by party discipline, penalize the repetitive absence of their employees. Several elected representatives mention in this regard that they could not have taken up their posts were it not for a decree in 2005 facilitating the anticipated retirement with the aim of relieving the civil service. If teachers do not have at their disposal their own resources to redistribute, as do local notables, their profession allows them to mobilize and build up the loyalty of militants or future militants, to take part in trustful relations and in "local popular practices" (Mischi, 2003, p. 91), to equally develop a multiplicity of relations with the party through the development of sports associations, night classes etc...

In 2003, the PJD elected municipal councilors who for the most part had hardly any political experience. The candidates were chosen in a rather deliberate way outside the ranks of party parliamentarians, in order to "widen the political camp for many militants." (W. PJD elected representatives, Casablanca, July 2008) In a common "rejet de la brigue" (Bennani Chraibi, 2005, p. 119), the elected representatives recall that they did not choose to present themselves or to be representatives, but rather the militants selected the candidates of the party through their vote. The deliberation of the local section is determining for the make-up of the lists ${ }^{13}$ : the electoral adventure thus escapes suspicion of personal ambition while it seems to be mainly a matter of devotion.

\footnotetext{
11 Dans ces 8 circonscriptions casablancaises, le PJD a recueilli 72980 voix contre 47272 pour le second parti, le Parti de l'Istiqlal.

12 See the contribution by M. Bennani Chraibi to this volume.

13. Des frictions portant sur la constitution de certaines listes aux législatives de 2007 montrent cependant que le bureau central peut imposer ses choix contre l'avis des militants locaux (comme par exemple à Casablanca-Anfa, où le PJD s'est associé au Parti des forces citoyennes).
} 
The elected PJD representatives are characterized notably by their youth, presented as a pledge of candor and dynamism. In 2003, the average age of the new elected local representatives in Casablanca was 47.2 years; it was 39.8 years for the elected representatives of the PJD. Political inexperience paradoxically appears as a guarantee of efficiency: deprived of any past experience in the arena of power, the newly PJD elected adopt more easily the attitude of elected representatives of the arrondissement.

In parallel, the party demands expertise and professionalisation in local governance. After devoting itself to the issue of reforming the Charter in the 2003 parliament, it militates henceforth for reform of the electoral law, by defending notably the abolishment of the threshold of representation in order to avoid the balkanization of City Councils and encourage the formula "a city =a party". The PJD declares itself the porte-parole of the local space and pays particular attention to the specialization of its representatives. To that goal, the Association of the local elected PJD representatives (jam iyya muntakhabin al'adâla wa al-tanmiya) organizes training sessions for elected representatives of the party. It is presided over by the emblematic mayor of Temara, supported by the vice-president of the City Council of Casablanca, in charge of urbanism.

More than an individual professionalization (the elected PJD representatives have a difficulty in living off politics and highlight the material challenges that they face), it is an institutional professionalisation that is at stake. The latter operates through a rationalization of political work where the individual makes way for the party and rely on a distinct militant devotion.

The ethos of professionalization can be equally found in the division of labor between the elected PJD representatives according to their experience in the professional world. It goes without saying, for instance, that the management of finance issues is assigned to a graduate of financial economics and business management from Toulouse. On the other hand, the management of the Lydec file by an aesthetic surgeon seemed less directly evident and provoked amused but also admiring remarks by party colleagues. At the same time, it shows the importance and the prestige accorded to the degree itself: "At this level of studies, we can understand everything," confirmed the elected representative in question.

Political party discipline and specialization are equally manifested in the coordination of work: "When we interfere in the Council, we interfere with knowledge of the cause, it is a responsibility. We prepare the interventions, we coordinate among each other." (A. elected PJD representative, Vice-president of the arrondissement, elected to the City Council of Casablanca).

The integration of the PJD in the local political game thus contributed to its normalization. At the same time, the forms of authority deployed by its representatives, as well as the repertoires of action they draw upon, renew the rules of local power. The elected PJD representatives claim the status of novice and the professionalization of their role at the same time. They present themselves as generous notables engaged in causes where only the interests of their voters matter, while also donning the garb of disciplined servants of the party, devoted to the interest of the party machine. Through their outsider discourse and their rhetoric of renewal and of political virginity ${ }^{14}$, they advocate for a representation of the cities at the same time virtual - by trying to explain what the power of the party would be if they had not limited their candidatures - and virtuous - the

\footnotetext{
14. "Pour une commune efficace et un développement complet », programme du PJD pour les élections communales de 2003.
} 
accredited candidatures are "transparent" and the candidates "competent," capable of inventing a dynamic political life and of engaging citizens in decision-making ${ }^{15}$. Combining mediation activities, non-profitable practices and moral representations of the authority, the elected PJD representatives seek to impose themselves as new "social authorities" in politics ${ }^{16}$. This new forms of notables paradoxically associates militant trajectories and territory base, professionalization and vocation. But the comparison with more classical notable figures ends at the threshold of a/the strong dependency that links them to the party.

\section{CONCLUSION}

The election of Abdelilah Benkirane to the post of secretary-general during the PJD congress in July 2008 created surprise on the outside as well as in the heart of the party. The pundits effectively banked on a new victory for Saâd Eddine El Othmani (elected for the first time in April 2004), who embodied the strategy of normalization and political integration of the party. The new leader chosen by the militants is known for his polemical declarations, sometimes judged as intolerant and populist. Meanwhile, he is still considered a moderate. Indeed, he hopes to "moralize political life", but the application of values issued from the Islamic referential that he invokes has to contribute primarily to the fight against corruption ${ }^{17}$. On the national as well as on the local level, the application of an Islamic ethic has to contribute to the reinvention of a political morale based on consensual values; a morale which the Islamists advocate to be the only ones to implement through their party discipline.

The experience of the PJD in the municipalities since 2003 shows an organized and disciplined political group, which, however, promotes sometimes contradictory strategies and watchwords: budget management versus political reform, dissidence versus participation. The PJD councilors, by presenting themselves as the local elected representatives par excellence, embody new political figures and follow the royal command and the international calls for decentralization. Faced with the limited means offered by local institutions, the members of the party push to rethink the technical and political modalities of the municipalities.

The elections held in June 2009 renewed the process. The PJD managed to field candidates in $40 \%$ of all electoral districts, including all cities and some rural communities. The party announced its goal to be first ${ }^{18}$. In Meknès, established as a laboratory for PJD management, electors disowned the party and the PJD was beaten. The General Secretary of the Modernity and Authenticity Party,a new party founded by Fouad Ali El Himma, a close collaborator of Mohammed VI and a direct competitor of

\footnotetext{
15. Ibid.

16. Voir la présentation éditoriale du dossier «Trajectoires de la notabilité, I. Pratiques et stratégies », Politix, 17 (65), 2004, p. 12.

17. Florence Beaugé, «Abdelilah Benkirane, chef du parti islamiste PJD, veut "moraliser la vie politique au Maroc" ", Le Monde, 6 août 2008.
}

${ }^{18}$ Declaration of M. Benkirane French press service, AFP. June 6, 2009. 
the PJD in the Meknès poll, explained, "The PJD was sanctioned because the party had management Meknès poorly. Moroccans saw for themselves that the PJD did not have a monopoly on virtue" ${ }^{\text {"19 }}$. If the PJD is the sixth party in terms of the total number of seats controlled (out of a total 1513 seats) it remains the strongest party among the large cities (745 seats). In other words, party development continues to be focused on a strategy of winning among the kingdom's urban circumscriptions.

\section{BIBLIOGRAPHY}

Auyero Javier, 2001, Poor People's Politics: Peronist Survival Networks and the Legacy of Evita, Durham/London: Duke University Press.

Bennani ChraÏBi Mounia, 2005, «Mobilisations électorales à Derb Soltan et à Hay Hassani (Casablanca) », in BENNANi ChraÏBI Mounia, CATUSSE Myriam, SANTUCCI JeanClaude (ed.), Scènes et coulisses de l'élection an Maroc: les législatives 2002, Paris, Karthala IREMAM.

BENNANI-CHRAÏвI Mounia, 2008, “'Hommes d'affaires' versus 'profs de fac.' La notabilisation parlementaire d'un parti de militants au Maroc," Revue internationale de politique comparée, vol. 15, n², pp. 205-219.

BENNANI-CHRAÏBI Mounia, 2008, "De nouveaux 'défenseurs du trône’?”, Les Cabiers de l'Orient, n90 pp. 9-22.

CATUSSE Myriam, (forthcoming), "Décentraliser la démocratie? Réformes institutionnelles et "bonne gouvernance" au Maroc ", in MASSARDIER Gilles, VARDAR Deniz (ed.), Démocratie, démocraties, Paris, L'Harmattan, under publication.

CATusse Myriam, 2001, "Affaires, scandales et urnes de verre à Casablanca. Les ambiguités de la démocratie locale à l'ère de la bonne gouvernance ", Annuaire de l'Afrique $d u$ Nord 2000-2001, CNRS Éditions, vol. XXXVIV.

CATusse Myriam, 2008, Le temps des entrepreneurs. Politique et transformations du capitalisme au Maroc, Paris : Maisonneuve et Larose.

DE Miras Claude (ed.), 2005, Intégration à la ville et services urbains an Maroc, Rabat, INAU/IRD.

ElyagouBi Abdelkader, 2005, "Les élections communales de 2003, maillon du processus démocratique au Maroc," bachelor's thesis in public law, Fez, Université Sidi Mohamed ben Abdellah. See http://www.memoireonline.com/01/07/318/m_electionscommunales-2003-processus-democratique-maroc0.html.

GOIRAND Camille, 2000, La politique des favelas, Paris : Karthala/CERI.

LECLERC-Olive Michèle (ed.), 2006, Affaires locales : de l'espace social communautaire à l'espace public politique, Paris, Karthala, GEMDEV

MisCHI Julian, 2003, “Travail partisan et sociabilités populaires : observations localisées de la politisation communiste," Politix, n63.

RoussiLlon Alain, 1989, Sociétés islamiques de placement de fonds et "ouverture économique », Le Caire, CEDEJ, dossiers du CEDEJ.

19 Quoted by H. Bennani, "Beyond Victory" (Au delà d'une victoire), Le Journal hebdomadaire, n401, 26/06/2009. 
SALGON Jean-Michel, 2008, "Élections législatives : la transition avortée," Les Cabiers de l'Orient, nº 90 , pp. 39-50.

SMAOUI Selim, 2009, «La probité comme argument politique : la campagne du PJS à Hay Hassani », in ZAKI L. (ed.), Terrains de campagne au Maroc. Les élections législatives de 2007, Paris, Karthala, pp. 273-298.

TOZY Mohammed, 1999, Monarchy and Political Islam in Morocco, Paris, Presses de Sciences Po.

WAZIF Mohamed, 2009, "Abdelbari Zemzemi, du minbar au Parlement. Pluripartisme islamiste et législatives marocaines (septembre 2007)," in ZAKI L. (ed.), Terrains de campagne au Maroc. Les élections législatives de 2007, Paris, Karthala, pp. 299-330.

ZAKI Lamia, 2005, Pratiques Politiques au bidonville, Casablanca (2000-2005), PhD thesis in political science, Paris, Institut d'Etudes Politiques.

ZAKI Lamia, 2008, "Le clientélisme, vecteur de politisation en régime autoritaire?", in DABENE Olivier, GEISSER Vincent and MASSARDIER Gilles (ed.) Autoritarismes démocratiques et démocraties autoritaires au XXI siècle: convergences Nord-Sud, Paris: La Découverte, pp. 157-180.

ZEGHAL Malika, 2005, Les islamistes marocains : le défi à la monarchie, Casablanca/Paris, Le Fennec/La Découverte. 